Article

\title{
Application of HEC-HMS Model for Flow Simulation in the Lake Tana Basin: The Case of Gilgel Abay Catchment, Upper Blue Nile Basin, Ethiopia
}

\author{
Bitew G. Tassew ${ }^{1,2, *}$, Mulugeta A. Belete ${ }^{1}$ and K. Miegel ${ }^{2}$ \\ 1 Bahir Dar Institute of Technology, Bahir Dar University, P.O. Box 26 Bahir Dar, Ethiopia; \\ mulugetaazeze94@gmail.com \\ 2 Faculty of Agricultural and Environmental Sciences, University of Rostock, Satower 48, 18051 Rostock, \\ Germany; konrad.miegel@uni-rostock.de \\ * Correspondence: bitewgnt@yahoo.com; Tel.: +251-912845532
}

Received: 16 January 2019; Accepted: 20 February 2019; Published: 10 March 2019

\begin{abstract}
Understanding the complex relationships between rainfall and runoff processes is necessary for the proper estimation of the quantity of runoff generated in a watershed. The surface runoff was simulated using the Hydrologic Modelling System (HEC-HMS) for the Gilgel Abay Catchment $\left(1609 \mathrm{~km}^{2}\right)$, Upper Blue Nile Basin, Ethiopia. The catchment was delineated and its properties were extracted from a $30 \mathrm{~m} \times 30 \mathrm{~m}$ Digital Elevation Model (DEM) of the Lake Tana Basin. The meteorological model was developed within HEC-HMS from rainfall data and the control specifications defined the period and time step of the simulation run. To account for the loss, runoff estimation, and flow routing, Soil Conservation Service Curve Number (SCS-CN), Soil Conservation Service Unit Hydrograph (SCS-UH) and Muskingum methods were used respectively. The rainfall-runoff simulation was conducted using six extreme daily time series events. Initial results showed that there is a clear difference between the observed and simulated peak flows and the total volume. Thereafter, a model calibration with an optimization method and sensitivity analysis was carried out. The result of the sensitivity analysis showed that the curve number is the sensitive parameter. In addition, the model validation results showed a reasonable difference in peak flow (Relative Error in peak, $\mathrm{RE}_{\mathrm{P}}=1.49 \%$ ) and total volume (Relative Error in volume, $\mathrm{RE}_{\mathrm{V}}=2.38 \%$ ). The comparison of the observed and simulated hydrographs and the model performance $(\mathrm{NSE}=0.884)$ and their correlation $\left(R^{2}=0.925\right)$ showed that the model is appropriate for hydrological simulations in the Gilgel Abay Catchment.
\end{abstract}

Keywords: Gilgel Abay; HEC-HMS; Lake Tana Basin; model; peak flow; rainfall-runoff; simulation

\section{Introduction}

Adequate knowledge of rainfall-runoff processes is vital to estimate the amount of runoff produced within a given catchment. Knowing the amount of runoff within a given catchment is important for sustainable water resources project planning and management. The activities to estimate runoff volumes and flood peaks can be easily simplified by adopting a modelling concept and by understanding rainfall partitioning and the principal factors triggering runoff [1]. The type of the modelling approach normally depends on the purpose, data availability and ease of use [2].

Rainfall-runoff models are often used as a tool for a wide range of tasks, such as the modelling of flood events, the monitoring of water levels during different water conditions or the prediction of floods [3]. Generally, hydrological models can be classified as stochastic and deterministic. The stochastic models will produce outputs that have partial randomness but the deterministic models on the other hand do not give randomness. Cunderlik [4] further classified deterministic hydrologic 
models into three major categories. Firstly, the lumped model, which assesses the catchment response simply at the outlet without obviously counting for an individual sub-basins response. Secondly, the semi-distributed model, which is partly permitted to change in space with a division of the catchment into a number of sub-basins. The third type of model is the distributed model, which permits its parameters to change in place at a resolution normally chosen by the client.

Distributed hydrological models such as the European Hydrological System Model (MIKE-SHE) and Modular Modeling System (MMS), and semi-distributed models like the Hydrological Engineering Center Hydrological Modelling System, Soil and Water Assessment Tool (SWAT),Topography Based Hydrological Model (TOPMODEL), Hydrologiska Byråns Vattenbalansavdelning (HBV) and Hydrological Simulation Program-Fortran (HSPF) are developed for a runoff estimation based on the data availability and complexity of the hydrological systems. Flood modelling has been greatly improved in recent years with the advent of geographic information systems, "radar-based" rainfall estimation using next-generation radar (NEXRAD), high-resolution digital elevation models, and distributed hydrological models [5]. More recently, flood modelling has been further improved with the advent of service-oriented architecture and numerical weather predictions [6]. In the case of flood predictions, rainfall-runoff models are very practical because they are even useful in the catchments with a limited amount of input data.

The Hydrologic Modelling System HEC-HMS, which is a hydrologic modelling software developed by the US Army Corps of Engineers Hydrologic Engineering Center (HEC) is an integrated modelling tool for all hydrologic processes of dendritic watershed systems. It consists of different component processes for rainfall loss, direct runoff, and routing. HEC-HMS has become very popular and been adopted in many hydrological studies because of its ability in the simulation of runoff both in short and longtime events, its simplicity to operate, and use of common methods [7]. Hydrographs developed by HEC-HMS either directly or in conjunction with other software's are used for studies of urban drainage, water availability, future urbanization impact, flow forecasting, flood damage reduction, floodplain regulation, and systems operation [8].

Previous studies on HEC-HMS proved its ability to simulate and forecast streamflow based on different datasets and catchment types [9]. Most of these studies clearly indicated that the results of the model simulation were location specific, in that different combinations of a model set containing the loss methods, runoff transform methods, and baseflow separation techniques were found to respond variably [10]. In this regard, a study conducted by Al-abed et al. [11] on the Al-Zarqa Basin in Jordan using a monthly streamflow showed that the HEC-HMS model can give more acceptable results than other models. Other researchers who used the model in different areas also have gotten satisfactory results. Radmanesh et al. [12] calibrated and validated the HEC-HMS model in the Yellow River watershed in Southwestern Iran. Sardoii et al. [13] used the HEC-HMS and Geographic Information System GIS to simulate the rainfall-runoff process in the Amirkabir watershed. Fallah [14] applied the HEC-HMS model to simulate the river flow in the Mohammadabad watershed located in the North of Iran. Yusop et al. [15] used the HEC-HMS for predicting the runoff in the Oil Palm Catchment. Yener et al. [16] simulated the rainfall-runoff process by dividing the basin into three sub-basins: Kirazdere, Kazandere, and Serindere, whereby each sub-basin was modeled with its own parameters.

Although the HEC-HMS model has been tested and calibrated at a global scale, little effort has been made in the context of Ethiopian catchments [17]. The Upper Blue Nile (Abay) Basin, which covers an area of $199,000 \mathrm{~km}^{2}$, has extensive agricultural practices and unpredicted flood events. It has been seriously affected by land degradation and flood problems, especially in the lowlands [18]. The Gilgel Abay Catchment which is part of this basin faces the same problem. Therefore, an accurate estimation of the peak flow and total volume from the respective rainfall events is critically important to implement appropriate soil and water conservation, erosion control, and flood protection measures in time.

Despite the different modelling activities that are practiced in the basin, the HEC-HMS model was not tested, calibrated, and validated in the Gilgel Abay Catchment. Therefore, the objectives 
of this study were: To develop the rainfall-runoff model and assess the runoff potential of the catchment; and to calibrate and validate the model and fix the corresponding calibrated values for future hydrological investigations in similar catchments within the basin and the nearby basins.

\section{Methodology}

\subsection{Study Area Description}

The Gilgel Abay Catchment has an area of $1609 \mathrm{~km}^{2}$ at the gauging station near Piccolo, with elevations ranging between $1800 \mathrm{~m}$ and $3530 \mathrm{~m}$ above mean sea level (Figure 1). Geographically it is bounded by the northern latitudes from $10^{\circ} 56^{\prime}$ to $11^{\circ} 23^{\prime}$ and eastern longitudes from $36^{\circ} 48^{\prime}$ to $37^{\circ} 24^{\prime}$. Soils are characterized by clay, clay loam, and silt loam textures, with each texture sharing similar proportions of the catchment area [19]. The majority of the catchment is a basalt plateau with gentle slopes, while the southern part has a rugged topography. The climate is semi-humid with a mean annual rainfall of $1300 \mathrm{~mm}$ (1990-2012), more than $70 \%$ of which falls in the summer monsoon season (June to September).
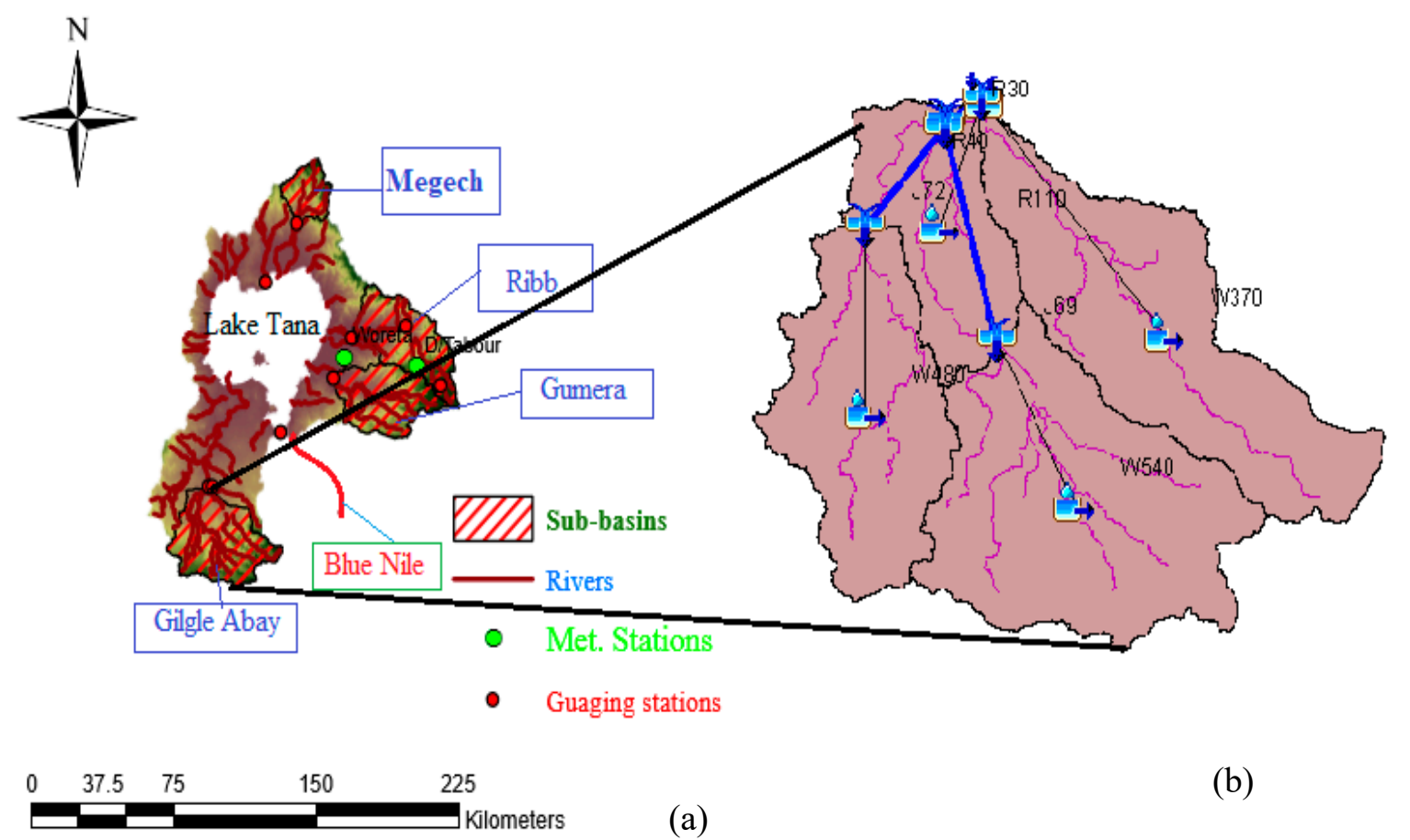

(a)

Figure 1. Location of (a) Lake Tana Basin with hydro-meteorological stations and (b) Basin Model of Gilgel Abay Catchment.

\subsection{Data}

Input data as an important part of rainfall-runoff modelling can be categorized into hydro-meteorological (rainfall and stream flow) and physiographic (digital elevation model, land use/ cover and soil type) databases.

The data required to build an HEC-HMS model are elevation, land use/cover, percent impervious area, soil, and hydrograph information. These datasets were used to determine stream/sub-basin characteristics and hydrologic parameter estimations.

The basic information on physiographic characteristics of the catchment (elevation and slope) was extracted from a $30 \mathrm{~m} \times 30 \mathrm{~m}$ resolution digital elevation model of the Lake Tana Basin which was downloaded from the web for free. The Geographic Information System (ArcGIS 10.2) interface of the HEC-GeoHMS model was used to further process the DEM data. Terrain pre-processing and 
basin processing tools were used to generate the characteristic parameters of the basin and input files for HEC-HMS.

The calibration and validation of hydrological models are the fundamental operations that should be considered in many modelling studies which require a series of runoff data [20]. For this study the streamflow data (1990-2014), land use/cover, and soil data were collected from the Hydrology and GIS Departments of the Ministry of Water, Irrigation and Electricity of Ethiopia whereas precipitation data (1990-2014) were collected from the National Meteorological Agency of Ethiopia. Tables 1 and 2 below indicate the events selected for the calibration and validation and physiographic characteristics of each sub-catchment respectively.

Table 1. Rainfall events selected for calibration and validation.

\begin{tabular}{cccccc}
\hline Events & Start Date & Start Time & End Date & End Time & Remark \\
\hline Event 1 & 02 July 1996 & $00: 00$ & 26 July 1996 & 00:00 & Calibration \\
Event 2 & 16 August 1996 & $00: 00$ & 31 August 1996 & $00: 00$ & Calibration \\
Event 3 & 14 July 2006 & $00: 00$ & 02 August 2006 & $00: 00$ & Calibration \\
Event 4 & 05 August 2006 & $00: 00$ & 17 August 2006 & $00: 00$ & Calibration \\
Event 5 & 01 September 2006 & $00: 00$ & 19 August 2006 & $00: 00$ & Calibration \\
Event 6 & 02 July 2008 & $00: 00$ & 23 July 2006 & $00: 00$ & Calibration \\
Event 7 & 02 August 2008 & $00: 00$ & 15 August 2008 & $00: 00$ & Validation \\
Event 8 & 26 August 2008 & $00: 00$ & 11 September 2008 & $00: 00$ & Validation \\
Event 9 & 04 July 2012 & $00: 00$ & 20 July 2012 & $00: 00$ & Validation \\
Event 10 & 08 August 2012 & $00: 00$ & 23 August 2012 & $00: 00$ & Validation \\
\hline
\end{tabular}

Table 2. Physiographic characteristics of the catchment.

\begin{tabular}{cccccc}
\hline Sub-Catchment Code & Area $\left(\mathbf{k m}^{\mathbf{2}}\right)$ & Perimeter $\mathbf{( k m )}$ & Slope (\%) & CN * & Lag (h) \\
\hline W340 & 232.59 & 124.800 & 17.73 & 85.00 & 3.26 \\
W370 & 480.07 & 189.240 & 23.30 & 84.67 & 4.44 \\
W480 & 356.49 & 155.560 & 18.6 & 84.47 & 3.88 \\
W540 & 540.22 & 175.520 & 24.97 & 84.87 & 2.94 \\
\hline
\end{tabular}

*-Dimensionless.

\subsection{Models}

\subsubsection{HEC-HMS Model}

The HEC-HMS model is physically based and conceptually semi-distributed model designed to simulate rainfall-runoff processes in a wide range of geographic areas, from large river basin water supplies and flood hydrology to small urban and natural watershed runoffs. It easily operates huge tasks in relation to hydrological studies, including losses, runoff transform, open channel routing, analysis of meteorological data, rainfall-runoff simulation, and parameter estimation [21,22]. Moreover, the HEC-HMS uses separate models that compute runoff volume, models of direct runoff, and models of baseflow. It has nine different loss methods, some of which are designed primarily for simulating events, while others are intended for continuous simulation. It also has seven different transformation methods. For example the Snyder Unit Hydrograph Yilma and Moges [17] and Clark Unit Hydrograph Banitt [23] methods have been applied successfully to simulate long-term stream flows elsewhere.

HEC-GeoHMS was used to create a basin model and a meteorological model, and to control specifications before running the model. The basin model and the basin features were taken as the background map file and imported to HEC-HMS 4.2. Since we do not have observation stations in each sub-basin, the precipitation values were estimated by the most commonly used Thiessen Polygon method and weights were worked out in HEC-GeoHMS software. The method was selected because of its easy application; accuracy depends on the sampling density. The boundaries are often oddly shaped, as transitions between polygons are often abrupt and continuous variables are often not well 
represented. During calibration, a daily simulation time step was used in estimating the parameters of the selected methods. Each model run combines a basin model, meteorological model, and control specifications with run options to obtain results. It contains four main components: (1) An analytical model to calculate overland flow runoff as well as channel routing, (2) an advanced graphical user interface illustrating hydrologic system components with interactive features, (3) a system for storing and managing data—specifically large, time variable data sets—and (4) a means for displaying and reporting model outputs [24].

The Soil Conservation Service Curve Number, SCS Unit hydrograph, and Muskingum routing methods were selected for each component of the runoff process as runoff depth, direct runoff, and channel routing respectively. These methods were chosen on the basis of applicability and limitations of each method, availability of data, suitability for the same hydrologic condition, stability, wide acceptability, and well established researcher recommendations. The baseflow was not considered because in short duration event modelling and for small sub-basins the contribution of base flow is insignificant for flood flows $[25,26]$.

\section{(i) Loss Model}

The loss models in HEC-HMS normally calculate the runoff volume by computing the volume of water that is intercepted, infiltrated, stored, evaporated, or transpired and subtracting it from the precipitation. In this study, the Soil Conservation Service Curve Number loss method was selected to estimate direct runoff from a specific or design rainfall [27]. It has several advantages over other methods in that: It is a simple conceptual method for the estimation of the direct runoff amount from a storm rainfall event, and is well supported by empirical data; it relies only on the curve number, which is a function of the soil type and land use/cover that are the major runoff-producing watershed characteristics. However, there are several problems associated with the SCS-CN method. For example, it does not account for rainfall intensity and temporal variation of rainfall as well as for average ground slope [28]. Despite the above problems, the SCS-CN loss method was chosen for HEC-HMS analysis in this study because of the following reasons: It is commonly used in different environments and provides better results compared to initial and constant loss rate method [13]. Its calculation is made easier by the fact that only a few variables need to be estimated based on hydrologic soil group, land use and slope maps. And despite its simplicity, it yields results that are as good as those of complex models [29].

The SCS-CN model assumes that the accumulated rainfall-excess depends upon the cumulative precipitation, soil type, land use and the previous moisture conditions as estimated in the following relationship [21].

$$
\mathrm{P}_{\mathrm{e}}=\frac{\left(\mathrm{P}-\mathrm{I}_{\mathrm{a}}\right)^{2}}{\mathrm{P}-\mathrm{I}_{\mathrm{a}}+\mathrm{S}}
$$

where Pe is the accumulated precipitation excess at time $t(\mathrm{~mm}) ; \mathrm{P}$ is the accumulated rainfall depth at time $t(\mathrm{~mm})$; Ia is the initial abstraction (initial loss) $(\mathrm{mm})=\alpha \mathrm{S}, \alpha$ is 0.2 as a standard; and $S$ is the potential maximum retention $(\mathrm{mm})$, a measure of the ability of a watershed to abstract and retain storm precipitation.

In the curve number method, the runoff is directly proportional to the precipitation with an assumption that the runoff is produced after the initial abstraction of $20 \%$ of the potential maximum storage [30].

The maximum retention, $\mathrm{S}$, and watershed characteristics are related through an intermediate dimensionless parameter, the curve number $(\mathrm{CN})$ as:

$$
S=25400-\frac{254 \times C N}{C N}
$$

where $\mathrm{CN}$ is the SCS curve number used to represent the combined effects of the primary characteristics of the catchment area, including soil type, land use, and the previous moisture condition. The CN 
values range from 100 (water bodies) to approximately 30 for permeable soils with high infiltration rates [21].

(ii) The Transform Model

The transform prediction models in HEC-HMS simulate the process of the direct runoff of excess precipitation on the watershed, and they transform the precipitation excess in point runoff. In this study, the Soil Conservation Service Unit Hydrograph model was chosen to transform excess precipitation into runoff. It is a parametric model based on the average Unit Hydrograph (UH) derived from gauged rainfall and runoff data of a large number of small agricultural watersheds throughout the United States. The SCS proposed the Unit Hydrograph (UH) model, and it is included in the HEC-HMS program. The lag time $\left(\mathrm{T}_{\mathrm{lag}}\right)$ is the only input for this method. It is the time from the center of mass of excess rainfall to the hydrograph peak and is calculated for each watershed based on the time of concentration Tc, as:

$$
T_{\text {lag }}=0.6 T_{c}
$$

where $\mathrm{T}_{\text {lag }}$ and $\mathrm{T}_{\mathrm{c}}$ are in minute.

The time of concentration can be estimated based on basin characteristics including topography and the length of the reach by Kirpich's formula [31].

$$
T_{\mathcal{C}}=0.0078 \times\left(\frac{L^{0.77}}{S^{0.385}}\right)
$$

where $\mathrm{L}$ is the reach length in feet, and $\mathrm{S}$ is the slope in $(\mathrm{ft} / \mathrm{ft})$.

(iii) Routing Model

As the flood runoff travels through the channel reach, it becomes attenuated due to channel storage effects. The routing models available in HEC-HMS account for this attenuation. The Muskingum method, which was developed by McCarthy [32], is a popular lumped flow routing technique which was selected for this study.

The Muskingum routing method is a simple approximate method to calculate the outflow hydrograph at the downstream end of the channel reach from the inflow hydrograph at the upstream end. Among many models used for flood routing in rivers, it is a straightforward hydrological flood routing technique used in natural channels [33], and it has been extensively applied in river engineering practice since its introduction in the 1930s [34]. In this model calibration, two parameters are needed; travel time $(\mathrm{K})$ of the flood wave through routing reach; and dimensionless weight $(\mathrm{X})$ which corresponds to the attenuation of the flood wave as it moves through the reach. The routing parameters in the models are usually derived through calibration using measured discharge hydrographs [35].

$$
S=\mathrm{K}[\mathrm{XI}+(1-\mathrm{X}) \mathrm{Q}],
$$

in which the prism storage in the reach is $\mathrm{KQ}$, where $\mathrm{K}$ is a proportionality coefficient, and the volume of the wedge storage is equal to $K X(I-Q)$, where $X$ is a weighting factor having a range of $0 \leq X \leq 0.5$.

\subsubsection{HEC-GeoHMS Model}

Background map files, basin model files, meteorological model files, and a grid cell parameter are created by HEC-GeoHMS which are input to a hydrological model HEC-HMS. The following steps adopted from Merwade [36] were used to extract the basin model: (i) Data collection such as DEM, soil and land use/cover; (ii) data assembly; (iii) terrain preprocessing. This latter part of the HEC-GeoHMS processing step helps to drive the drainage network from the input DEM processing, such as flow direction, flow accumulation, stream definition and segmentation, catchment polygon processing, drainage line processing and adjoint catchment processing; (iv) Hydrologic Modelling System (HMS) Project Setup: The input files for the HEC-HMS project were developed using the HMS 
project set up menu in HEC-GeoHMS, this helps to copy all the terrain preprocessing data to the HEC-HMS project; (v) basin processing; (vi) the extraction of basin and stream characteristics such as length, upstream and downstream elevations, and river slopes. It can help to extract the physical characteristics of sub-basins, such as longest flow path, basin centroid, centroid elevation, centroidal longest flow lengths, and basin slopes; (vii) the estimation of hydrologic parameters, such as the curve numbers, the percentage impervious area and time of concentration initial values are estimated using HEC-GeoHMS model processing; (viii) the creation of HMS model files, such as background shapefile, the basin model, meteorological model file, and a project file.

HEC-GeoHMS extension in ArcGIS was used to delineate the boundary of the area by considering the geographical reference point of the hydrological gauging station as the outlet point of the Gilgel Abay Catchment. Further HEC-GeoHMS processing of the DEM produced four sub-basins, five routing reaches, five junctions, and the major physiographic characteristics of the catchment as shown in Figure 1 and Table 2.

\subsection{Model Calibration and Validation}

A sensitivity analysis is usually undertaken in most modelling studies $[15,20]$. It is a necessary process to identify the key parameters and parameter precision required for calibration. The most fundamental sensitivity analysis technique utilizes partial differentiation, whereas the simplest method involves perturbing parameter values one at a time [37]. In this study, the sensitivity analysis was performed by changing the parameter values in the range of $\pm 25 \%$ with $5 \%$ intervals. Zelelew and Melesse [10] and Majidi and Shahedi [38] conduct a sensitivity analysis by changing the parameter values in the range of $\pm 30 \%$ with $5 \%$ intervals until the best fit between the observed and simulated parameters in the given hydrograph was obtained. Another study by Sardoii et al. [13] used a parameter change of $\pm 15 \%$ with a $5 \%$ interval in order to analyze the sensitivity of the calibration parameters in the Amirkabir Dam Watershed in Iran. The sensitivity parameters were then selected based on their effect on peak discharge and total volume. Thereafter, the model calibration was done with the Univariate Gradient optimization package and Peak-Weighted Root Mean Square Error (PWRMS) objective function because of their simplicity and performance (Deng et al., 2010, as cited by Jin et al. [26]. In this study, ten flood events (six for calibration and four for validation) recorded in the period from 1990-2014 were selected for calibration and validation purposes (Table 1). Watershed parameters such as curve number, infiltration coefficients, time of concentration, and baseflow may need modification to produce the best fit between model and observations. For validation, the simulated data as predicted by the model must be computed and compared with the observed data and statistical tests of error functions must be carried on.

Statistical evaluation techniques like relative bias error functions proposed by Najim [39], Nash-Sutcliffe Efficiency (NSE) by Nash and Sutcliffe [40], which is equal to one minus the ratio of the mean square error and standard deviation of measured data time series [41], and coefficient of determination $\left(R^{2}\right)$ as described in Neter et al. [42] were applied to evaluate the performance of the model and the selected loss and transform methods.

\section{Results and Discussion}

\subsection{Calibration}

In analyzing a flood event, the most important aspect of the hydrograph is the peak flow, because the peak flow corresponds to the maximum downstream flooding. In contrast, peaks that are significantly less than the maximum may correspond to increased water levels, but not necessarily a flood event. The results of the hydrological model in this study showed a reasonable fit between the model and observations after optimization; the hydrograph shape and timing of peaks matched well, although the model tended to overestimate the runoff before optimization (Table 3). In the majority of events, the hydrograph shape was accurately reproduced in the model output. However, the volume 
of runoff was overestimated in events 3, 4, and 6 and underestimated for the remaining Events (1, 2 , and 5).The calibration of the model improved the results greatly by decreasing and increasing the overestimated and underestimated volume of the runoff respectively.

The modelling results of peak discharge, total volume, and their relative errors with respect to the observed data, the Nash Sutcliffe Efficiency and coefficient of determination values during calibration are mentioned in Table 3 below. Figure 2 (Events 1, 3, and 6) and 3 (Events 1, 4, and 6) show the simulated and observed hydrographs and their correlation values respectively. Only sample calibrated events are presented in the Figures 2 and 3.

Table 3. Simulated (before and after optimization) and observed peak discharges and total volume and after optimization error functions.

\begin{tabular}{|c|c|c|c|c|c|c|c|c|c|c|}
\hline \multirow{3}{*}{ Events } & \multicolumn{4}{|c|}{ Peak Discharge $\left(\mathrm{m}^{3} / \mathrm{s}\right)$} & \multicolumn{4}{|c|}{ Total Volume (mm) } & \multirow{3}{*}{ NSE } & \multirow{3}{*}{$\mathbf{R}^{2}$} \\
\hline & \multicolumn{2}{|c|}{ Simulated } & \multirow{2}{*}{ Observed } & \multirow{2}{*}{$\mathrm{RE}_{\mathbf{P}}$} & \multicolumn{2}{|c|}{ Simulated } & \multirow{2}{*}{ Observed } & \multirow{2}{*}{$\mathbf{R E}_{\mathbf{V}}$} & & \\
\hline & BOP & AOP & & & BOP & AOP & & & & \\
\hline Event 1 & 341.8 & 310.6 & 313.8 & 1.02 & 206.56 & 276.02 & 275.83 & -0.07 & 0.812 & 0.857 \\
\hline Event 2 & 365.2 & 286.7 & 277.7 & -3.24 & 112.01 & 146.00 & 154.03 & 5.21 & 0.707 & 0.856 \\
\hline Event 3 & 505.8 & 358.6 & 355.5 & -0.87 & 242.31 & 154.67 & 160.85 & 3.84 & 0.769 & 0.803 \\
\hline Event 4 & 511.9 & 335.2 & 330.1 & -1.54 & 154.31 & 137.3 & 142.64 & 3.74 & 0.794 & 0.971 \\
\hline Event 5 & 427.2 & 227.1 & 217.3 & -4.51 & 138.93 & 160.3 & 158.49 & -1.14 & 0.788 & 0.876 \\
\hline Event 6 & 429.2 & 248.1 & 248.8 & 0.28 & 197.08 & 131.34 & 134.79 & 2.56 & 0.603 & 0.689 \\
\hline Mean & 430.2 & 294.4 & 290.5 & 1.91 & 175.2 & 167.6 & 171.1 & 2.76 & 0.746 & 0.842 \\
\hline
\end{tabular}

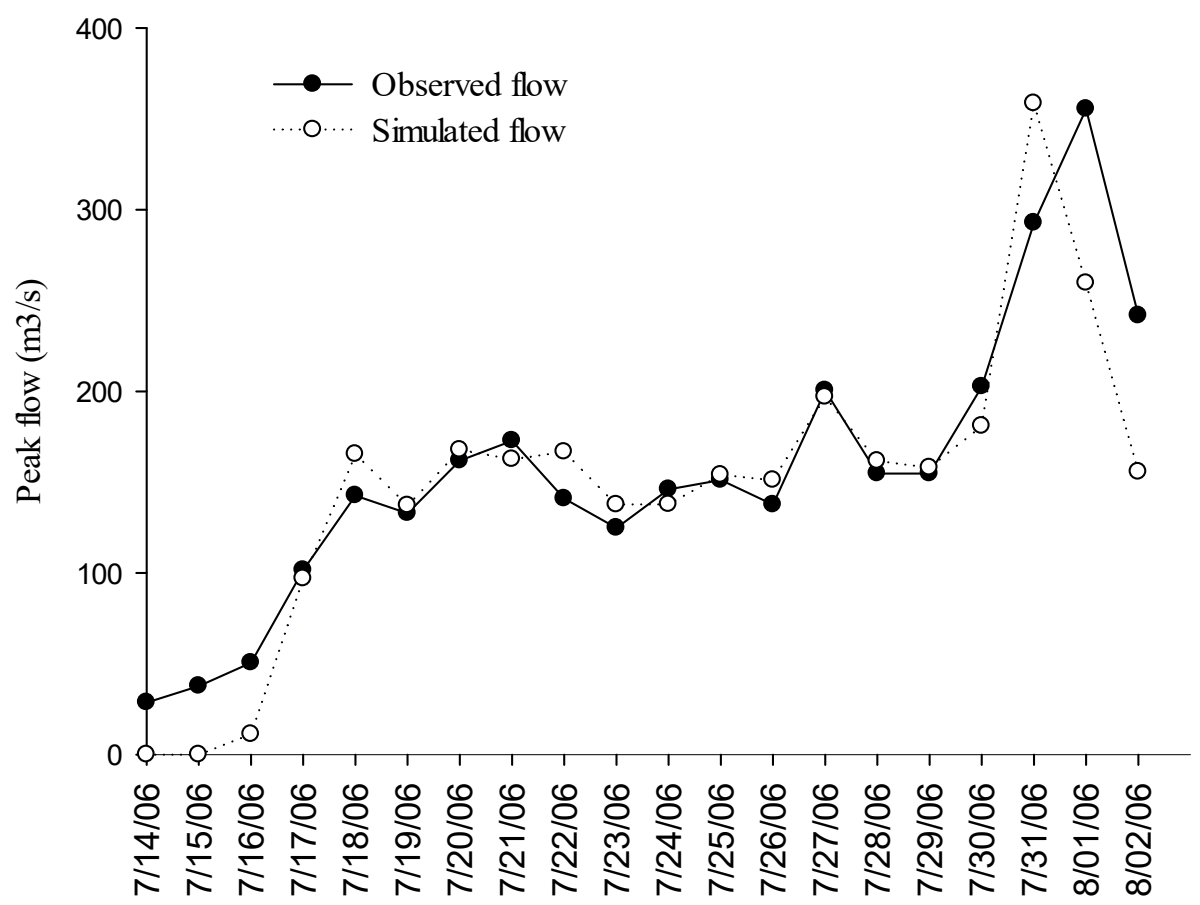

Date (days)

(a)

Figure 2. Cont. 


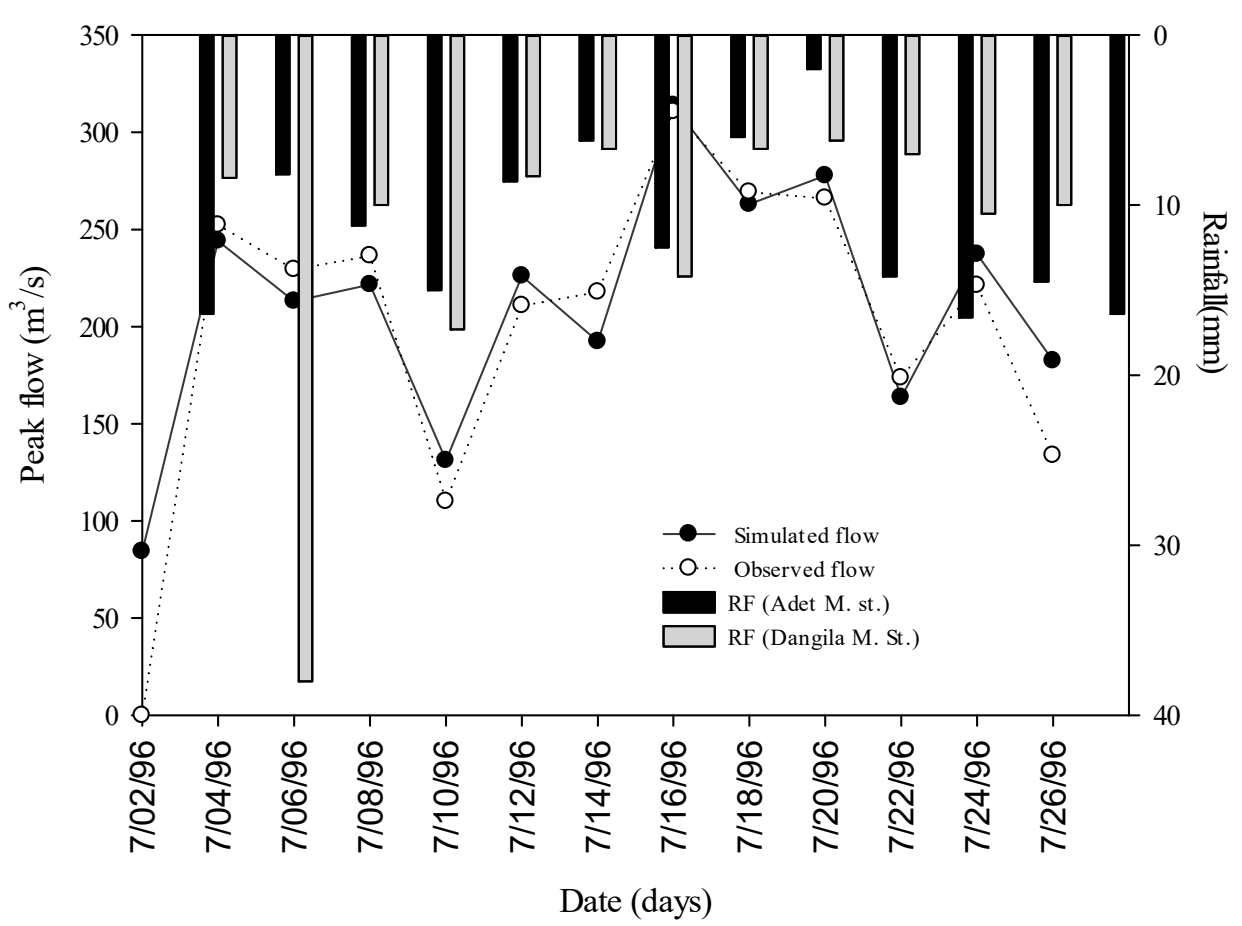

(b)

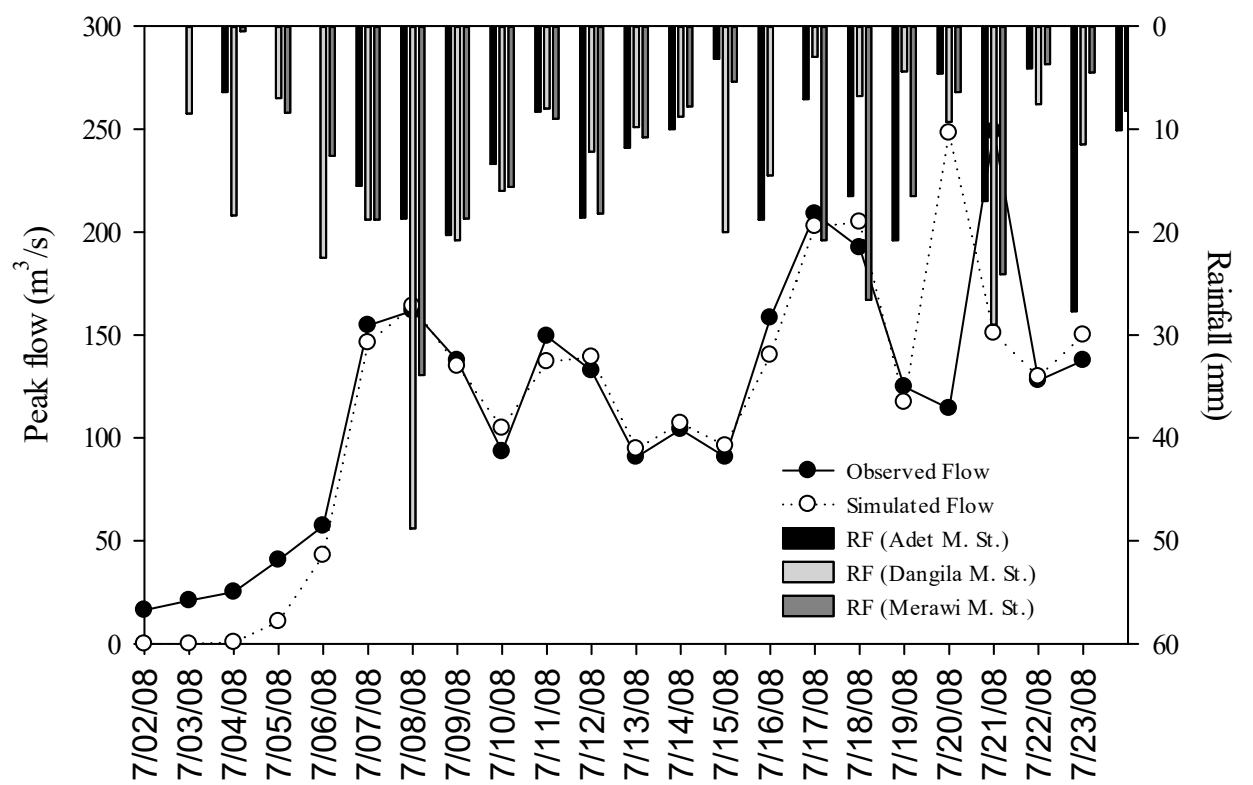

Date (days)

(c)

Figure 2. Comparison of simulated and observed hydrographs during calibration. (a) Model output for event 3 (14 July-02 August, 2006), (b) rainfall of contributing stations and simulated and observed hydrographs of Event 1 (02-26 July, 1996), and (c) rainfall of contributing stations and simulated and observed hydrographs of Event 6 (02-23 July, 2008). 


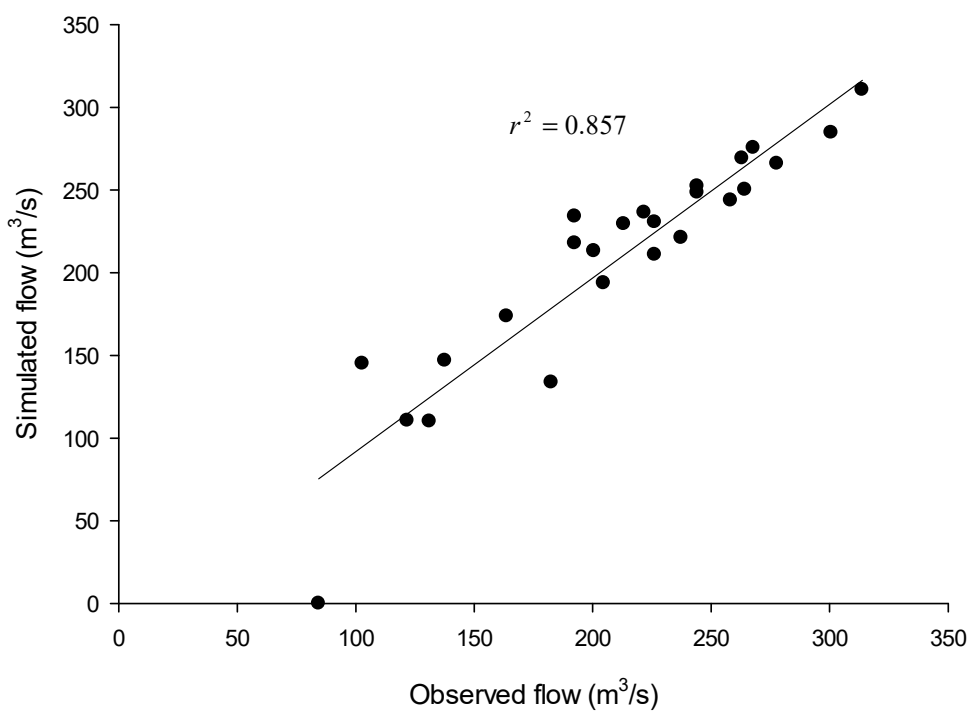

(a)

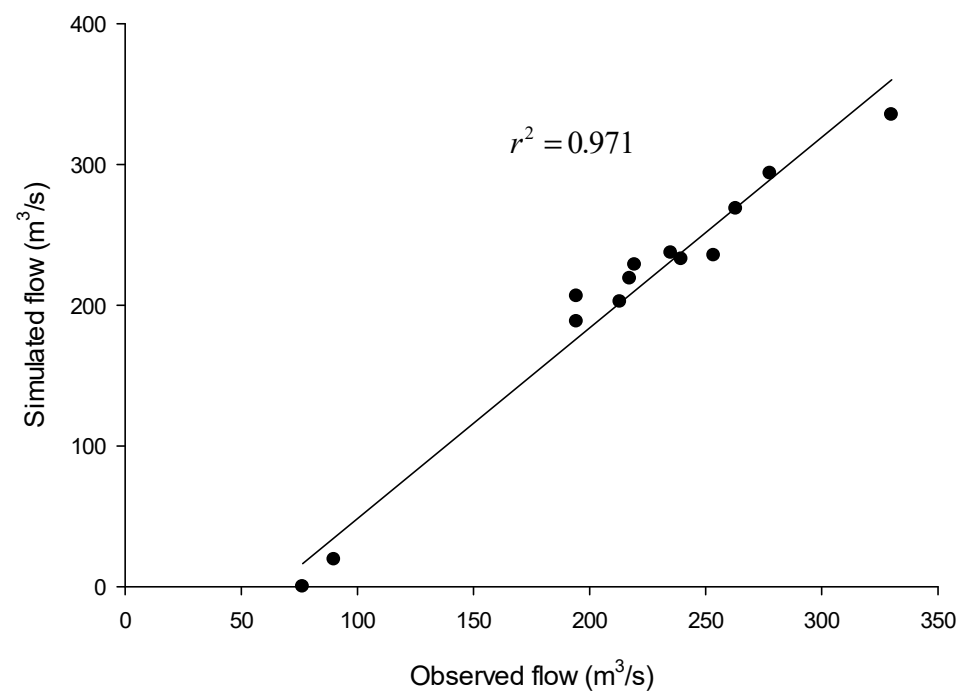

(b)

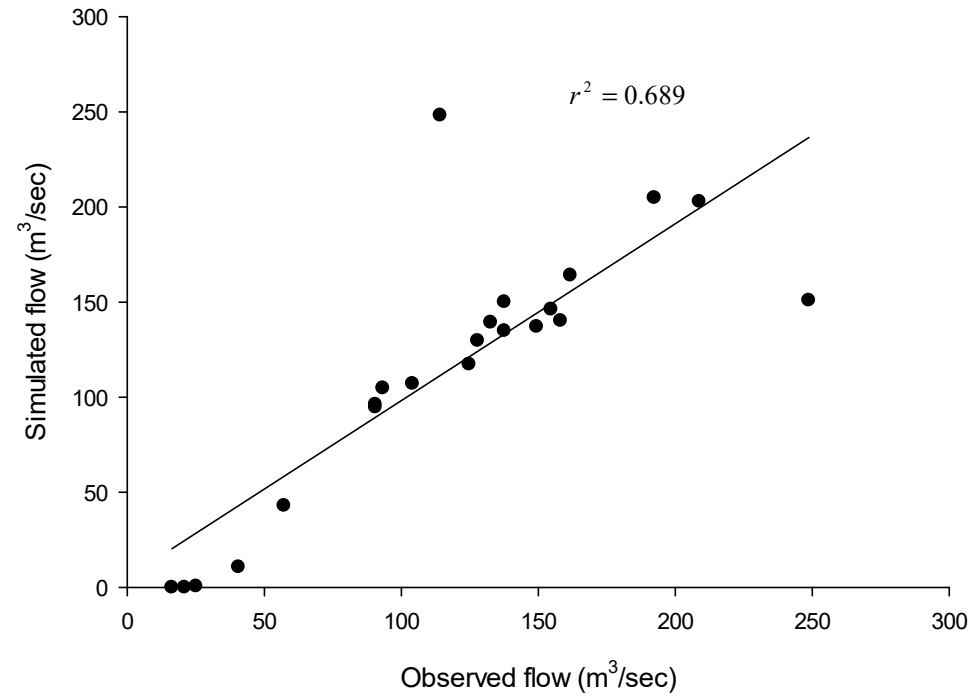

(c)

Figure 3. Correlation between observed and simulated flow during calibration (a) Event 1, (b) Event 4, and (c) Event 6. 
As mentioned in Section 2.4, six extreme events were selected for calibration from a 25 year rainfall series data. The selection of rainfall-runoff events is a critical step for event hydrologic modelling and model calibration/validation [9]. The selection depends on many factors, such as rainfall characteristics, watershed properties and availability and completeness of rainfall and stream monitoring data. Flood analysis tends to use large events. However, considering that the scale of the events reflect the range of the applicability and performance of the model [43]. The events of this study were selected by comparing the runoffs produced for the respective rainfalls (a rainfall event with a higher amount of runoff is selected). Table 4 summarizes the initial and optimized parameters of the catchment and Table 5 shows the optimized parameter values of each event during calibration.

Table 4. Calculated and optimized parameters of the catchment.

\begin{tabular}{ccccc}
\hline \multirow{2}{*}{ S.No. } & Methods & Parameter & \multicolumn{2}{c}{ Values } \\
\cline { 3 - 5 } & & & Calculated & Optimized \\
\hline \multirow{2}{*}{1} & Loss rate parameter & CN scale factor & 1.1892 & 0.8977 \\
& & Ia scale factor & 0.9815 & 1.0527 \\
2 & Runoff Transform & Impervious area (\%) & 0.0 & 0.0 \\
\multirow{2}{*}{3} & Routing Method constants & Lag time & 217.738 & 217.738 \\
& & $\mathrm{~K}$ & 0.5 & 0.5 \\
& & $\mathrm{X}$ & 0.1 & 0.1 \\
\hline
\end{tabular}

Table 5. Optimized parameter values of each event during calibration.

\begin{tabular}{cccccc}
\hline Parameters & Ia Scale Factor & CN Scale Factor & $\mathbf{T}_{\text {lag }}$ & $\mathbf{K}$ & $\mathbf{X}$ \\
\cline { 1 - 4 } Events & & & & & \\
\hline Event 1 & 0.83672 & 1.1721 & 217.738 & 0.5 & 0.1 \\
Event 2 & 0.97046 & 0.8813 & 217.738 & 0.5 & 0.1 \\
Event 3 & 1.515 & 0.91532 & 217.738 & 0.5 & 0.1 \\
Event 4 & 1.015 & 0.81121 & 217.738 & 0.5 & 0.1 \\
\hline Event 5 & 0.98892 & 1.0074 & 217.738 & 0.5 & 0.1 \\
Event 6 & 0.9898 & 0.59913 & 217.738 & 0.5 & 0.1 \\
Mean & 1.0527 & 0.8977 & 217.738 & 0.5 & 0.1 \\
\hline
\end{tabular}

In the rainfall-runoff modelling of the study area, the parameters curve number scale factor and initial abstraction scale factor show a high variability and parameters of routing $(K$ and $X)$ are constant in the calibrated events. These results demonstrate the impact of basin topography, soil type, land use and other catchment characteristics.

According to the result of the flood volume relative error, $\mathrm{RE}_{\mathrm{v}}$, as can be seen in Table 3, the error is relatively small for all flood events with absolute values less than $10 \%$. This may be due to the sub-humid attributes: The flood runoff is dominated by infiltration excess under the condition of short but intensive rainfall, or by the combination of infiltration and saturation excess under the condition of long-lasting rainfall of various intensities. From Figure 2 it is possible to conclude that runoff in all events is caused by the combination of infiltration and saturation excess due to strong intensity rainfall. The calculated values of the percent error both in total volume and peak flow between simulated and observed values in all simulations before optimization was very high, which falls in the range between the absolute value of 8.2 to $50.64 \%$ for the total volume and 8.9 to $96.6 \%$ for the peak flow, with mean values of $23.96 \%$ and $48.07 \%$, respectively. Considering this result, a sensitivity analysis was done to identify the most sensitive parameter for the loss, transform, and routing methods. It was found that the curve number, initial abstraction, and lag time were more sensitive, less sensitive and insensitive parameters of the model, respectively. Nearly a similar result was obtained for the peak flow by Zelelew and Melesse [10] which ranges from 37.5 to $60.2 \%$, with a mean value of $50.1 \%$ for a model set containing the SCS loss method with Clark's unit hydrograph transform method combination. 
After optimization, the values in this study were reduced to 0.07 to $5.21 \%$ for the total volume and 0.28 to $4.51 \%$ for the peak flow, with mean values of $2.76 \%$ and $1.91 \%$, respectively (Table 3 ). The result is very good according to Najim et al. [39] and Sabzevari et al. [44], who recommended that the acceptable ranges of relative percent errors between the observed and simulated values should be below $\pm 20 \%$. The study by Cheng et al. [45] also indicated that the runoff model is considered good if the percentage error of the runoff volume is less than $20 \%$ according to the criteria for flood forecasting in China. In this statistical evaluation criterion, the positive values indicate model underestimation bias, and the negative values indicate model overestimation bias [46].

Figure 3 and Table 3 also show a relatively close agreement between the observed and simulated peak flow values at the period of calibration $\left(R^{2}=0.842\right)$ after optimization. More specifically, Event 6 had the lowest $R E_{p}(0.28)$ but an unexpected lower NSE (0.603) and $R^{2}(0.689)$ values. These might be due to high peak discharges as a result of more extreme rainfall in 20-21 of July 2008 and the modelling effect because the model simulation showed that the simulated peak is $24 \mathrm{~h}$ earlier than the observation. According to the classification range mentioned in Zou et al. [47] the mean correlation coefficient obtained in this study can be considered as strong $(>0.8)$. Considering the Nash-Sutcliffe Efficiency (NSE) criteria, better results were obtained between the simulated and observed values, with a mean NSE value of $74.6 \%$ (Table 3). Therefore, the model performs well. The model simulation can be judged as satisfactory if Nash-Sutcliffe Efficiency is greater than $50 \%$, good if it is greater than $65 \%$, and very good if it is greater than $75 \%$ [48]. Overall, in this study the three statistical evaluation criteria with mean values of $R E_{P}=1.91 \%, R E_{V}=2.76 \%, N S E=0.746, R^{2}=0.842$ showed good simulation between the estimated and observed values.

\subsection{Validation}

In this study, the validation of the simulated results (Table 6) of peak discharge, total volume, and their relative errors with respect to the observed data, the Nash-Sutcliffe Efficiency (NSE) and the coefficient of determination values are listed. Figure 4 (Events 8 and 9) and 5 (Events 7 and 9) showed the simulated and observed hydrographs and their correlation respectively. Only the sample validation events are presented in Figures 4 and 5.

Table 6. Simulated and observed peak discharge and total volume during validation.

\begin{tabular}{ccccccccc}
\hline \multirow{2}{*}{ Events } & \multicolumn{3}{c}{ Peak Discharge $\left(\mathbf{m}^{\mathbf{3}} \mathbf{s}\right)$} & \multicolumn{3}{c}{ Total Volume $(\mathbf{m m})$} & \multirow{2}{*}{ NSE } & \multirow{2}{*}{$\mathbf{R}^{\mathbf{2}}$} \\
\cline { 2 - 7 } & Simulated & Observed & $\mathbf{R E}_{\mathbf{P}}$ & Simulated & Observed & $\mathbf{R E}_{\mathbf{V}}$ & & \\
\hline Event 7 & 295.4 & 298.0 & 0.87 & 115.99 & 119.05 & 2.57 & 0.922 & 0.958 \\
Event 8 & 188.9 & 192.4 & 1.82 & 111.77 & 112.54 & 0.678 & 0.848 & 0.908 \\
Event 9 & 195.5 & 198.5 & 1.51 & 79.56 & 81.47 & 2.34 & 0.847 & 0.892 \\
Event 10 & 242.1 & 246.4 & 1.75 & 121.31 & 126.26 & 3.92 & 0.919 & 0.943 \\
Mean & 230.5 & $233 . .8$ & 1.49 & 107.16 & 109.83 & 2.38 & 0.884 & 0.925 \\
\hline
\end{tabular}

Four extreme events from 25 years rainfall series data, which are different from the events used for calibration, were selected for validation purpose (Table 1). The selection of the events was similar to the calibration events (see Section 3.1). The calibration model simulated the values of different runoff hydrographs, such as the peak flow and total volume by considering the mean of the optimized parameters shown in Table 5. The result showed that the simulated values are close to the observed ones for all the events (Table 6). The mean relative percent error between the observed and simulated values of peak flow and total volume is calculated to be $1.49 \%$ and $2.38 \%$, respectively.

Figure 5 and Table 6 also show relatively close agreement between the observed and simulated peak flow values during validation $\left(R^{2}=0.925\right)$. Considering the Nash-Sutcliffe Efficiency (NSE) criteria, better results were obtained between the simulated and observed values, with a mean NSE value of $88.4 \%$. According to Moriasi et al. [48], the model simulation can be judged as very good. Generally, in this study, the three statistical evaluation criteria with mean values of $R_{P}=1.49 \%$, 
$\mathrm{RE}_{\mathrm{V}}=2.38 \%$, NSE $=0.884$, and $\mathrm{R}^{2}=0925$ show good simulation between the estimated and observed values. The validation results (Table 6) were better than the calibration (Table 3 ) and the statistical evaluation criteria also performed better. A similar result was obtained by Gharib et al. [49] when they used the Modclark model to evaluate the simulation of the rainfall-runoff in the Tangrah watershed, Iran.

The overall simulation results of events selected for validation show us that there is a possibility of getting a good performance of the HEC-HMS model in predicting the peak flow and total volume in Gilgel Abay Catchment by using SCS-CN and SCS UH methods. Studies by Yilma and Moges [17] and Majidi and Shahedi [38] also obtained credible simulation results of the peak flow and total volume in the HEC-HMS model containing a combination of different loss and transform methods.

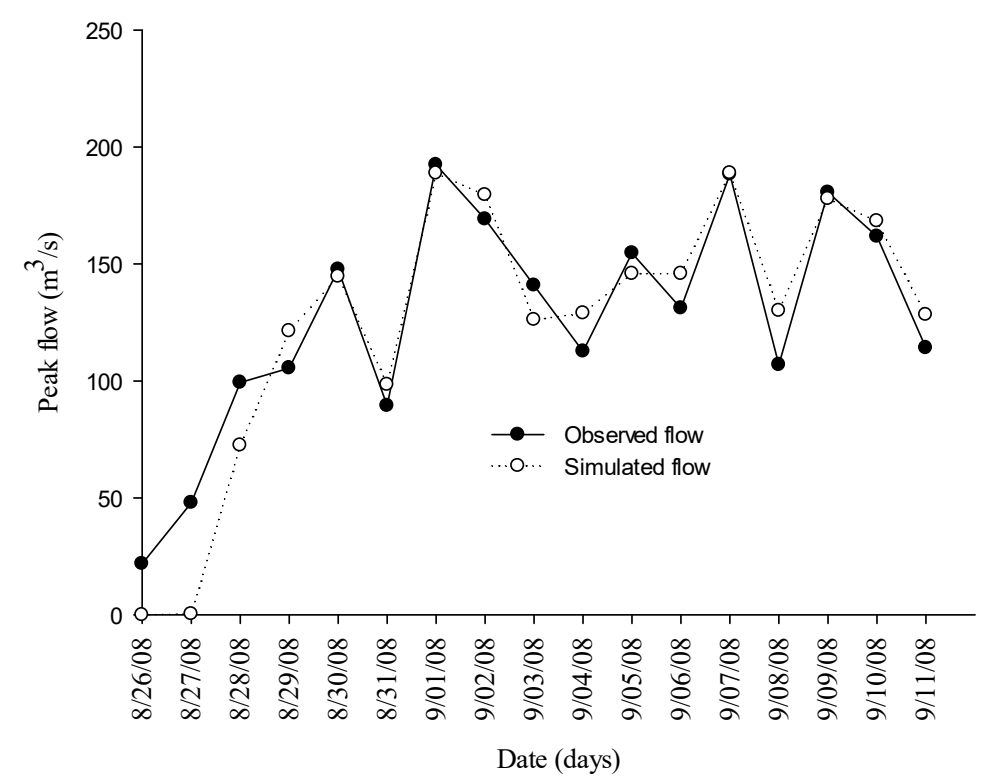

(a)

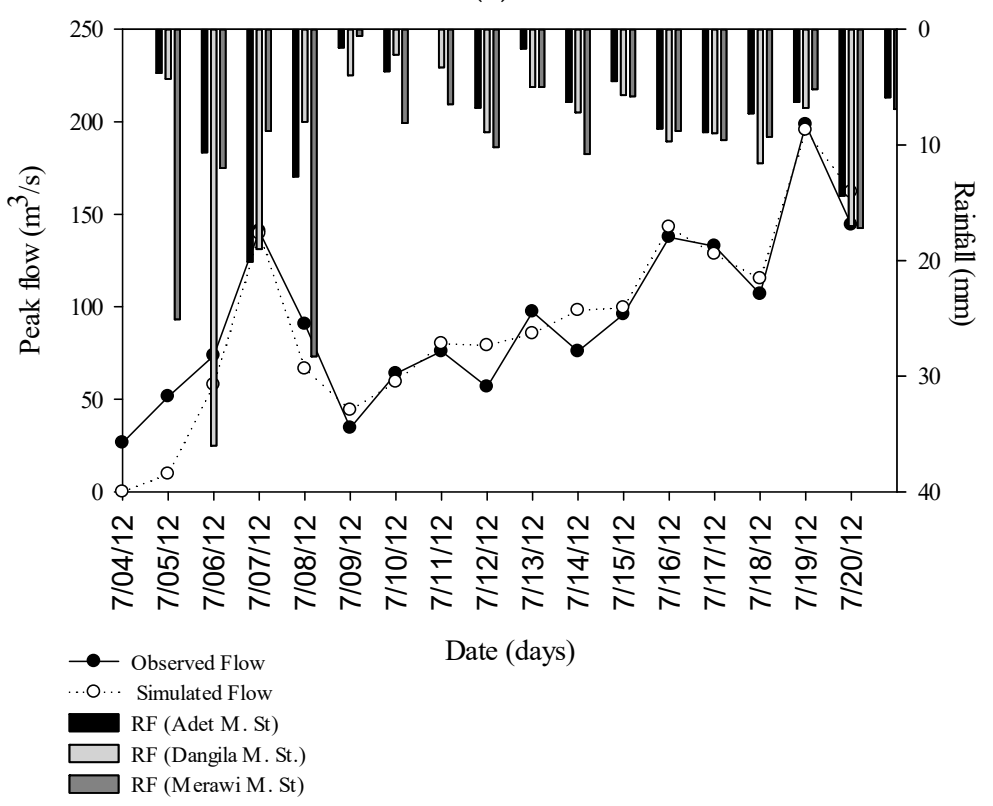

(b)

Figure 4. Comparison of simulated and observed hydrographs during validation (a) Model output for event 8 (26 August-11 September, 2008) and (b) Rainfall of contributing stations and simulated and observed hydrographs of Event 9 (04-20 July, 2012). 


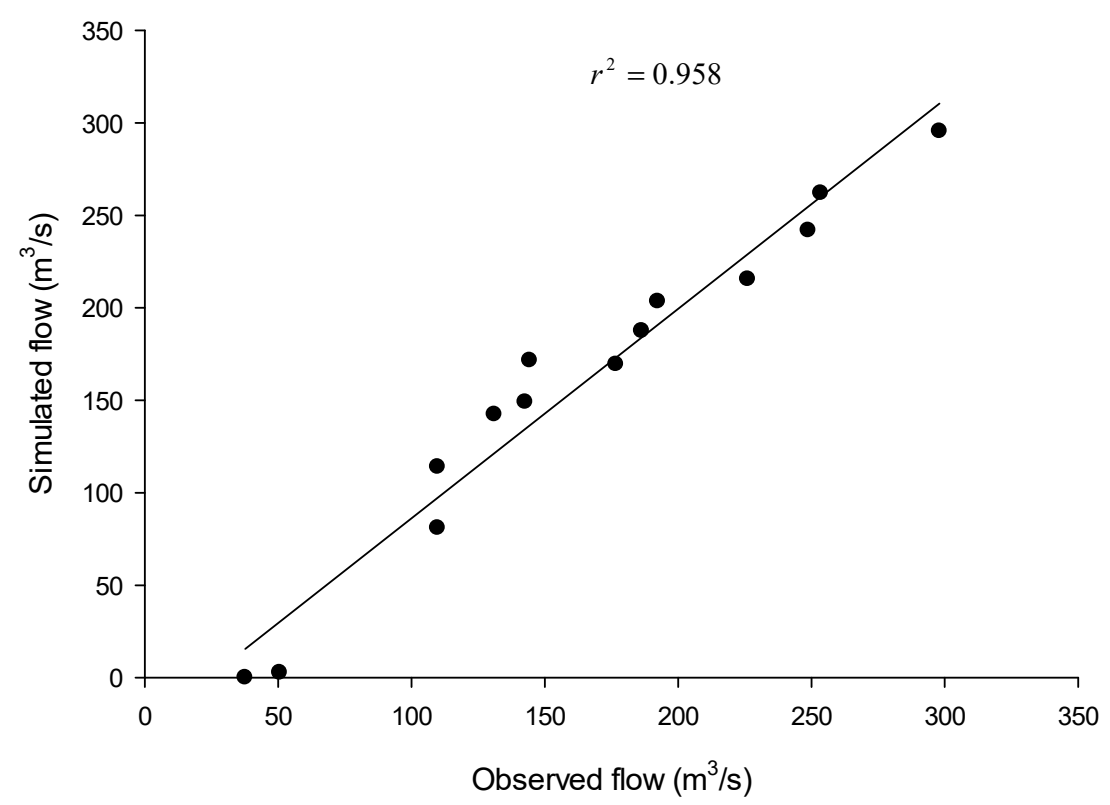

(a)

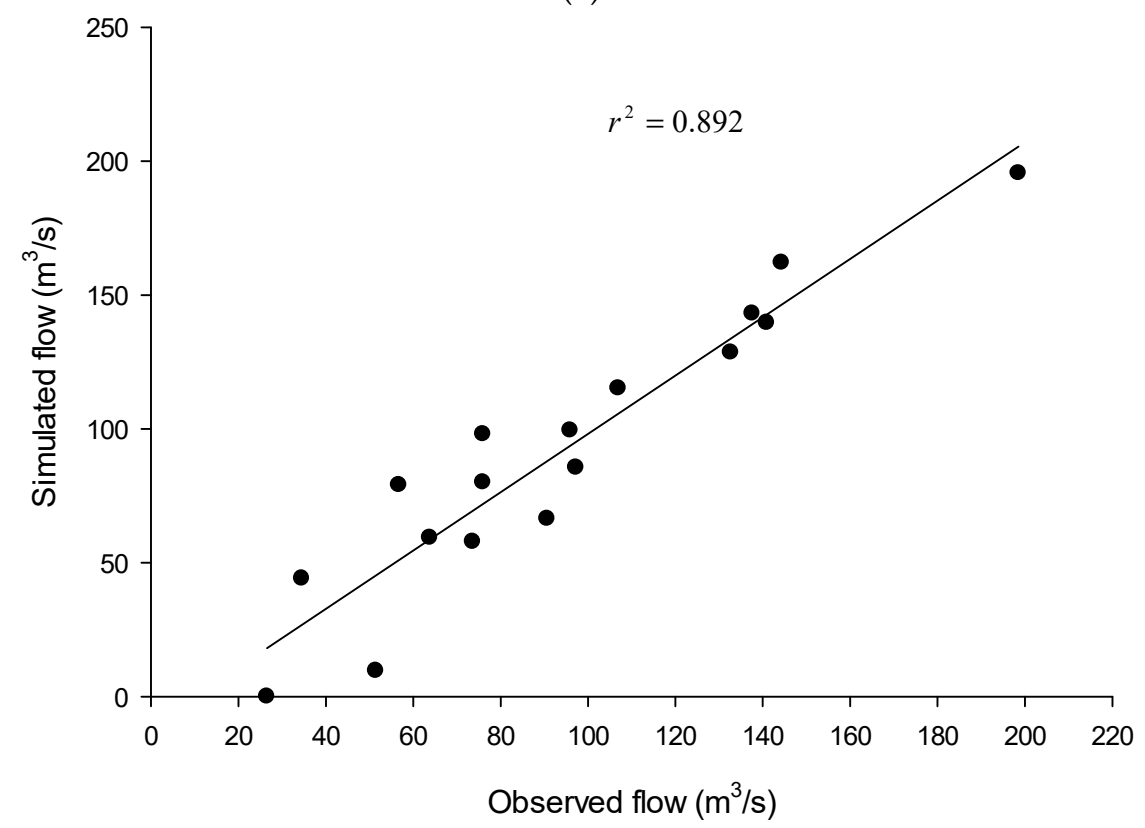

(b)

Figure 5. Correlation between observed and simulated flow values after validation (a) Event 7 (02-15 August, 2008) and (b) Event 9 (04-20 July, 2012).

From the results of the statistical evaluation criteria a good performance of the HEC-HMS model was obtained in simulating the runoff volume and peak flow with SCS loss and transform methods. However, in order to increase the performance of the model in simulating the runoff with these combinations, it is better to develop the local and regional curve number of the catchment instead of using the tabulated standardized $\mathrm{CN}$ values and to identify regional valid unit hydrographs. Zelelew [50] and Hawkins [51] also recommended the same.

Generally, the results of this study provide basic information on the extent of total volume and peak flow generated in the catchment from the respective rainfall events that in turn are useful for the planning, designing and management of different water resources activities. The results of these findings can also be used as a basic input data for further hydrological investigation for adjacent 
ungauged catchments by transferring the required calibrated parameters through regionalization and other techniques as explained by Jin et al. [52].

\section{Conclusions}

This study demonstrated that the HEC-HMS hydrological model is adaptable to tropical conditions. The model is based on the hydrological characteristics, topography, soil type and land use of the study area. Basin characteristics and initial values were analyzed using HEC-GeoHMS in ArcGIS in order to start the model calibration. The rainfall-runoff simulation was conducted using extreme rainfall events and initial results showed that there is a clear difference between observed and simulated peak flows and volumes in the study area. Therefore, the model calibration was conducted to optimize the parameters. To know the most influential parameter in the simulation a sensitivity analysis was carried out and the results showed that the curve number is the most sensitive parameter followed by the lag time. After optimization the peak flow and total volume of all events are very close to the observations with a very small error in peak and volume $(<10 \%)$. Overall performance of the HEC-HMS model was very good in terms of relative error functions, Nash-Sutcliffe Efficiency, and coefficient of determination based on the selected loss, transform and flow routing methods. So, it is possible to suggest that the calibrated parameters can be further used to other catchments in the basin and nearby basins.

Note that the verification results are not worse than the results obtained after calibration. This result is surprising since the verification results are more or less worse in general. Therefore, we conclude that there are relatively unique input-output relations and that the runoff formation is dominated by the only mechanism.

Finally, the methodologies developed in this research can also be applied in other ungauged catchments and regions with similar characteristics. We suggest further studies in the study catchment to generate more detailed information for modelling work by reviewing the efficiency of meteorological and hydrometric measurements (poor in quantity and quality during this study) in order to establish the optimal number of stations and their adequate distribution in the catchment.

Author Contributions: Conceptualization, B.G.T.; data curation, B.G.T.; formal analysis, B.G.T.; investigation, B.G.T.; methodology, B.G.T.; supervision, M.A.B. and K.M.; validation, B.G.T.; writing-original draft, B.G.T.; writing-review \& editing, B.G.T., M.A.B. and K.M.

Funding: This research received no external funding

Acknowledgments: The authors would like to acknowledge the Ethiopian Ministry of Water, Irrigation and Electricity for proving the flow, soil, and land use/cover data and the National Meteorology Agency of Ethiopia for providing the required rainfall data. We also want to acknowledge Mr. Aderaw Genetu Tassew for his professional assistance in language and grammar editing.

Conflicts of Interest: The authors declare no conflict of interest.

\section{References}

1. Zhang, W.W.; Fu, B.J.; Meng, Q.H.; Zhang, Q.J.; Zhang, Y.H. Effects of land-use pattern change on rainfall-runoff and runoff-sediment relations: A case study in Zichang watershed of the Loess Plateau of China. J. Environ. Sci. 2004, 16, 436-442.

2. Beven, K.J. Rainfall-Runoff Modelling: The Primer; John Wiley \& Sons: Chichester, UK; Wiley-Blackwell: Hoboken, NJ, USA, 2012.

3. Jia, Y.; Zhao, H.; Niu, C.; Jiang, Y.; Gan, H.; Xing, Z.; Zhao, Z.A. WebGIS-based system for rainfall-runoff prediction and real-time water resources assessment for Beijing. Comput. Geosci. 2009, 35, 1517-1528. [CrossRef]

4. Cunderlik, M.J. Hydrologic Model Selection Fort the CFCAS Project: Assessment of Water Resources Risk and Vulnerability to Changing Climatic Conditions; Department of Civil and Environmental Engineering, The University of Western Ontario: London, ON, Canada, 2003. 
5. Bedient, P.B.; Holder, A.; Benavides, J.A.; Vieux, B.E. Radar-based flood warning system applied to Tropical Storm Allison. J. Hydrol. Eng. 2003, 8, 308-318. [CrossRef]

6. Shi, H.; Li, T.; Liu, R.; Chen, J.; Li, J.; Zhang, A.; Wang, G. A service-oriented architecture for ensemble flood forecast from numerical weather prediction. J. Hydrol. 2015, 527, 933-942. [CrossRef]

7. Halwatura, D.; Najim, M. Application of the HEC-HMS model for runoff simulation in a tropical catchment. Environ. Modell. Softw. 2013, 46, 155-162. [CrossRef]

8. US Army Corps of Engineers. Hydrologic Modeling System, HEC-HMS. Quick Start Guide; US Army Corps of Engineers, Institute for Water Resources, Hydrologic Engineering Center: Davis, CA, USA, 2015.

9. Chu, X.; Steinman, A. Event and continuous hydrologic modeling with HEC-HMS. J. Irrig. Drain. E-Asce. 2009, 135, 119-124. [CrossRef]

10. Zelelew, D.; Melesse, A. Applicability of a Spatially Semi-Distributed Hydrological Model for Watershed Scale Runoff Estimation in Northwest Ethiopia. Water 2018, 10, 923. [CrossRef]

11. Al-Abed, N.; Abdulla, F.; Khyarah, A.A. GIS-hydrological models for managing water resources in the Zarqa River basin. Environ. Geol. 2005, 47, 405-411. [CrossRef]

12. Radmanesh, F.; Hemat, J.P.; Behnia, A.; Khond, A.; Mohamad, B.A. Calibration and assessment of HEC-HMS model in Roodzard watershed. In Proceedings of the 17th international conference of river engineering, Ahvaz, Iran, 2006.

13. Sardoii, E.R.; Rostami, N.; Sigaroudi, S.K.; Taheri, S. Calibration of loss estimation methods in HEC-HMS for simulation of surface runoff (Case Study: Amirkabir Dam Watershed, Iran). Adv. Environ. Biol. 2012, 6, 343-348.

14. Fallah, S. Simulation of maximum peak discharge in river tributaries using HEC-HMS model (Case study: Moha mmadabad watershed, Golestan province). Master's Thesis, University of Gorgan, Gorgan, Iran, 2001.

15. Yusop, Z.; Chan, C.; Katimon, A. Runoff characteristics and application of HEC-HMS for modelling stormflow hydrograph in an oil palm catchment. Water Sci. Technol. 2007, 56, 41-48. [CrossRef] [PubMed]

16. Yener, M.K.; Sorman, A.U.; Sorman, A.A.; Sensoy, A.; Gezgin, T. Modeling studies with HEC-HMS and runoff scenarios in Yuvacik Basin, Turkiye. Int. Congr. River Basin Manag. 2007, 4, 621-634.

17. Yilma, H.M.; Moges, S.A. Application of semi-distributed conceptual hydrological model for flow forecasting on upland catchments of Blue Nile River Basin, a case study of Gilgel Abbay catchment. Catchment Lake Res. 2007, 6, 1-200.

18. Merrey, D.J.; Gebreselassie, T. Promoting Improved Rainwater and Land Management in the Blue Nile (Abay) Basin of Ethiopia: Annexes. ILRI: Nairobi, Kenya; Department for International Development: London, UK, 2011.

19. Bitew, M.; Gebremichael, M. Assessment of satellite rainfall products for streamflow simulation in medium watersheds of the Ethiopian highlands. Hydrol. Earth Syst. Sci. 2011, 15, 1147-1155. [CrossRef]

20. Azam, M.; San Kim, H.; Maeng, S.J. Development of flood alert application in Mushim stream watershed Korea. Int. J. Disast. Risk Re. 2017, 21, 11-26. [CrossRef]

21. Feldman, A. Hydrologic Modeling System HEC-HMS Technical Reference Manua; US Army Corps of Engineers. Hydrologic Engineering Center: Davis, CA, USA, 2000.

22. US Army Corps of Engineers. Hydrologic Modeling System (HEC-HMS) Application Guide Version 3.1.0; Institute for Water Resources: Davis, CA, USA, 2008.

23. Banitt, A. Simulating a century of hydrographs e Mark Twain reservoir. In Proceedings of the 2nd Joint Federal Interagency Conference, Las Vegas, NV, USA, 27 June-1 July 2010.

24. Bajwa, H.; Tim, U. Toward immersive virtual environments for GIS-based Floodplain modeling and Visualization. In Proceedings of the 22nd ESRI User Conference, San Diego, CA, USA, 8-12 July 2002.

25. Kamali, B.; Mousavi, S. Automatic calibration of HEC-HMS model using multi-objective fuzzy optimal models. CEIJ 2014, 47, 1-12.

26. Jin, H.; Liang, R.; Wang, Y.; Tumula, P. Flood-runoff in semi-arid and sub-humid regions, a case study: A simulation of jianghe watershed in northern China. Water 2015, 7, 5155-5172. [CrossRef]

27. Environmental and Water Resources Instit. Curve Number Hydrology: State of the Practice; Hawkins, R.H., Ward, T.J., Woodward, D.E., Van Mullem, J.A., Eds.; American Society of Civil Engineers: Reston, VA, USA, 2009.

28. Mockus, V. Estimation of Total (and Peak Rates of) Surface Runoff for Individual Storms. Exhibit A in Appendix B, Interim Survey Report, Grand (Neosho) River Watershed; USDA: Washington, DC, USA, 1949. 
29. Lastra, J.; Fernández, E.; Díez-Herrero, A.; Marquínez, J. Flood hazard delineation combining geomorphological and hydrological methods: An example in the Northern Iberian Peninsula. Nat. Hazards 2008, 45, 277-293. [CrossRef]

30. Heshmatpoor, A. Identification runoff source area in tropical watershed. In Proceedings of the Postgraduate Qolloquium Semester, Kuala Lumpur, Malaysia, 26-29 October 2009.

31. Kirpich, Z. Time of concentration of small agricultural watersheds. Civ. Eng. 1940, 10, 362.

32. McCarthy, G.T. The unit hydrograph and flood routing. In Proceedings of the Conference of North Atlantic Division, Washington, WA, USA, 1938.

33. Shaw, E.M. Hydrology in Practice; T.J. International Ltd.: Padstow, UK, 1994.

34. Tewolde, M.H.; Smithers, J. Flood routing in ungauged catchments using Muskingum methods. Water SA 2006, 32, 379-388. [CrossRef]

35. Birkhead, A.; James, C. Muskingum river routing with dynamic bank storage. J. Hydrol. 2002, 264, 113-132. [CrossRef]

36. Merwade, V. Watershed and Stream Network Delineation Using ArcHydro Tools; School of Civil Engineering, Purdue University: West Lafayette, IN, USA, 2012; pp. 1-7.

37. Hamby, D. A review of techniques for parameter sensitivity analysis of environmental models. Environ. Monit. Assess. 1994, 32, 135-154. [CrossRef] [PubMed]

38. Majidi, A.; Shahedi, K. Simulation of rainfall-runoff process using Green-Ampt method and HEC-HMS model (Case study: Abnama Watershed, Iran). J. Hydraul. Eng. 2012, 1, 5-9.

39. Najim, M.M.M.; Babelb, M.S.; Loofb, R. AGNPS Model Assessment for a Mixed Forested Watershed in Thailand. ScienceAsia 2006, 32, 53-61.

40. Nash, J.E.; Sutcliffe, J.V. River flow forecasting through conceptual models part I-A discussion of principles. J. Hydrol. 1970, 10, 282-290. [CrossRef]

41. Gupta, H.V.; Kling, H.; Yilmaz, K.K.; Martinez, G.F. Decomposition of the mean squared error and NSE performance criteria: Implications for improving hydrological modelling. J. Hydrol. 2009, 377, 80-91. [CrossRef]

42. Neter, J.; Wasserman, W.; Kutner, M.H. Applied Statistical Models; Richard D. Irwin, Inc.: Burr Ridge, IL, USA, 1990.

43. Reed, S.; Koren, V.; Smith, M.; Zhang, Z.; Moreda, F.; Seo, D.J.; Participants, D.M.I.P. Overall distributed model intercomparison project results. J. Hydrol. 2004, 298, 27-60. [CrossRef]

44. Sabzevari, T.; Ardakanian, R.; Shamsaee, A.; Talebi, A. Estimation of flood hydrograph in no statistical watersheds using HEC-HMS model and GIS (Case study: Kasilian watershed). J. Water Eng. 2009, 4, 1-11.

45. Cheng, C.-T.; Ou, C.; Chau, K. Combining a fuzzy optimal model with a genetic algorithm to solve multi-objective rainfall-runoff model calibration. J. Hydrol. 2002, 268, 72-86. [CrossRef]

46. Gupta, H.V.; Sorooshian, S.; Yapo, P.O. Status of automatic calibration for hydrologic models: Comparison with multilevel expert calibration. J. Hydrol. Eng. 1999, 4, 135-143. [CrossRef]

47. Zou, K.H.; Tuncali, K.; Silverman, S.G. Correlation and simple linear regression. Radiology 2003, 227, 617-628. [CrossRef] [PubMed]

48. Moriasi, D.N.; Arnold, J.G.; Van Liew, M.W.; Bingner, R.L.; Harmel, R.D.; Veith, T.L. Model evaluation guidelines for systematic quantification of accuracy in watershed simulations. Trans. ASABE 2007, 50, 885-900. [CrossRef]

49. Gharib, M.; Motamedvaziri, B.; Ghermezcheshmeh, B.; Ahmadi, H. Evaluation Of Modclark Model For Simulating Rainfall-Runoff In Tangrah Watershed, Iran. Appl. Ecol. Env. Res. 2018, 16, 1053-1068. [CrossRef]

50. Zelelew, D.G. Spatial mapping and testing the applicability of the curve number method for ungauged catchments in Northern Ethiopia. J. Soil Water Conserv. 2017, 5, 293-301. [CrossRef]

51. Hawkins, R.H. Asymptotic determination of runoff curve numbers from data. J. Irrig. Drain. Eng. 1993, 119, 334-345. [CrossRef]

52. Jin, X.; Xu, C.Y.; Zhang, Q.; Chen, Y.D. Regionalization study of a conceptual hydrological model in Dongjiang basin, south China. Quat. Int. 2009, 208, 129-137. [CrossRef]

(C) 2019 by the authors. Licensee MDPI, Basel, Switzerland. This article is an open access article distributed under the terms and conditions of the Creative Commons Attribution (CC BY) license (http:/ / creativecommons.org/licenses/by/4.0/). 